\title{
Danışman Diyetisyen/Beslenme ve Diyet Uzmanı Olmanın Dayanılmaz Hafifliği
}

\author{
The Unbearable Lightness of Being a Consultant Dietitian/Nutrition and Diet Specialist
}

\section{Prof. Dr. Türkan Kutluay Merdol ${ }^{1}$}

Bu sayımızdaki editöryal yazım için bu başlığı seçtim. Çünkü bireylere beslenme ve diyet planları için danışmanlık yapmayı, romanlara ve filmlere konu olan "varolmanın dayanılmaz hafifliği” kadar önemli buluyorum.

Son üç aydır Dünya'yı kasıp kavuran COVID-19 salgını nedeniyle, medyada pek çok kişi, bağışıklık sistemimizi güçlendiren besinler konusunda konuşmaya başladı. Ylllardır, "beslenmenin bireye özel olduğunu” her mecrada anlatıp duruyorum. Çünkü, evrim süreci içinde homo sapiens sapiens (Düşünmeyi Düşünen İnsan) olarak tanımlanan ve bugünkü insanlarla özdeş kabul edilen insan, yer yüzünde 250.000 ylldır yaşıyor. $\mathrm{Bu}$ süreç içinde; genetik olarak getirdiği özellikler, yaşadığı travmalar, yaşanan doğa olayları ve yaşadığı bölgenin kendine özgü iklim özellikleri gibi pek çok faktörden etkilendiği için, bazı bölgelerde daha kısa, bazı bölgelerde daha uzun bir yaşam sürüyor. Bugün yeryüzünde ülke adları altında şekillenmiş insan topluluklarında beklenen yaşam süreleri, en uzunundan en aza göre ilk 10 ve son 10 ülke olarak Tablo 1'de görülmektedir (1). Antropologlara göre insan ömrü en çok 120 yıldır. Tabloda görüldüğü gibi dünya genelinde yaşam beklentisi ortalaması 72.6 yl olarak verilmektedir. Bazı ülkeler bu sürenin ancak yarısına ulaşabilirken, bazıları ancak 2/5'ine bazıları, 3/5’ten fazlasına ulaşmaktadır. Beklenildiği gibi bu değerler erkek ve kadın için farklılık göstermektedir. Türkiye için bu değer, bugün için 77.4 yll olarak verilmektedir ve kadınlarda 80.3 yll, erkeklerde 74.4 yıldır. Yaşam beklentisi temel olarak yaşanılan çevre, beslenme biçimi, fiziksel aktivite gibi etkenlerle birlikte, geçirilen psikolojik travmaların etkileriyle şekillenmektedir. Bu etkiler, yaşanılan ülkenin sosyoekonomik ve politik yapıları ile etkileştiğinden ülkenin bu bağlamda durumu geliştikçe yaşam beklentisi de doğal olarak artmaktadır.

Bireyler için tüm bu etkenlerle büyük farklılıklar yaratarak gelişen bedensel, biyolojik ve mental yapılarına uygun, bir başka deyişle bireye özel beslenme planları her birey için özel olarak hazırlanmasını gerektirdiğinden bu planların beslenme ve diyetetik konusunda eğitim almış ve deneyimi olan diyetisyenler/beslenme ve diyet uzmanları tarafından düzenlenmesini zorunlu kılmaktadır. $\mathrm{Bu}$ nedenle 19. yüzyıl sonlarında eğitimlerine başlanan bu meslek mensupları, gelişmiş ülkelerde sağlık hizmetinin temel ögesi olduğunda bireylerin ve toplumun sağlığı da istenen ve beklenen düzeye doğru sağlıklı bir şekilde evrilebilmiştir.

Sağlığı etkileyen etmenler içinde en temel bileşeni oluşturan beslenme ve fiziksel aktivite, bireyin kendi seçimi ile doğrudan ilgili olduğundan, bireyin bu yönlerden desteklenmesi ve kendisine özgü beslenme ve fiziksel aktivite planları yapılması büyük önem taşımaktadır. İnsanın gelişim sürecinde bedensel ve mental sağlığını korumak için başvurabileceği uzmanlık alanları da gelişmiştir ve bireyler genel sağlıkları için doktor yanında diyetisyen, fizyoterapist, psikolog gibi meslek mensuplarından yardım almaya başlamışlardır. Hiç şüphe yok ki, beslenme uygulamaları, egzersiz programları ve psikolojik

1. Atılım Üniversitesi, Sağlık Bilimleri Fakültesi, Beslenme ve Diyetetik Bölümü, Ankara, Türkiye • E-posta: info@beslenmevediyetdergisi.org (1) https://orcid.org/0000-0002-0783-947X 
destek programları da zaman içinde araştırma sonuçları doğrultusunda gelişmekte ve değişmektedir.

Toplumu oluşturan bireylerin sağlığı, toplumun sağlığını direk olarak etkilediğinden bireylere sağlık hizmetleri içinde destek olacak meslek mensupları bu değişimleri yakından takip etmek ve bireye özel programlar hazırlamada daha yetkin ve etkin olmak durumundadırlar. Sosyo-ekonomik olarak gelişmiş ülkeler, bu meslek mensupları istihdamında oldukça başarılıdır, ancak bizim gibi henüz bu anlamda gelişememiş ülkelerde bireylerin erişebileceği uzman sayısı yetersizdir. Bu yetersizlik farklı meslek mensuplarının bu alanlara yönelmesine neden olmuş ve medya aracılığı ile topluma verilen beslenme mesajları bireylerin kafasını karıştırmaya başlamıştır. Doktorların hastaları için düzenlediği tedavi planlarında beslenme ve fizik aktivite önemli bileşenleri oluşturduğundan, teşhisi koyan doktorun hastayı, diyetisyene, fizik aktivite için beden uygunluğunu değerlendirmede önemli görevler üstlenen fizyoterapistlere ve gerektiğinde psikologlara yönlendirmeleri gelişmiş ülke kriterlerinin öncelikli maddelerini oluşturur. Bu tedavi gurubu içinde yer alan ve hastanın "hastalığına göre" diyet ve beslenme planlarını düzenlemesi gereken diyetisyenlerin/ beslenme ve diyet uzmanlarının temel görevlerinden biri de toplumu yeterli, dengeli ve sağlıklı (YDS) beslenme konusunda bilinçlendirmeleri olduğundan, özel kliniklerini açarak kendilerine YDS konusunda başvuran danışanlarına bu anlamda yardımcı olmaktadırlar. Beslenme ve diyet danışmanlığı yapan diyetisyen/beslenme ve diyet uzmanlarının, danışanlarının bedensel ve biyokimyasal verilerine göre beslenme ve diyet planlarını yapabilmeleri için hastaları ile uzun süreli görüşmeler gerçekleştirmeleri gerekmektedir. Çünkü beslenme planlarını uygulama, hastanın doğru beslenme davranışı geliştirmesini gerektirir. Davranış geliştirme bilgi-tutum-davranış basamaklarının doğru bir şekilde uygulanması ile başarılabilecek bir durumdur. $\mathrm{Bu}$ nedenle diyetisyenin/beslenme ve diyet uzmanının davranış geliştirme için temel olan görüşme teknikleri, iletişim teknikleri, hastayı izleme teknikleri gibi konularında kendisini geliştirmesi gerekir (2). Türkiye Diyetisyenler Derneği zaman zaman diyetisyenler/ beslenme ve diyet uzmanları için bu konuda seminerler düzenlemektedir. Bireysel danışmanlık merkezleri açan meslektaşlarımızın bu ve benzeri seminerlere katılarak kendilerini geliştirmeleri, böylece hastalarına daha doğru ve etkili danışmanlık hizmeti vermeleri artık bir zorunluluktur.

İnsanoğlu, avcı-toplayıcı toplumdan yerleşik düzene geçmeye başladığı andan itibaren birbirlerine saygılı ve birbirlerinin haklarını ihlal etmeyecek şekilde ve birlikte yaşayarak örgütlenmek zorundaydı. $\mathrm{Bu}$ durum bir süre sonra yerleşim yerlerini, sonrasında siteleri (şehirleri) yarattı. Sitelerde birlik içinde yaşam da bazı kurallara uyum zorunluluğunu beraberinde getirdi. Özellikle ilk uygulamalarını öğrenebildiğimiz antik Yunan sitelerinde demokrasi kavramı bu nedenle gelişti ve oy hakkı olan halk, agoralarda toplanıp yönetim için kararlarını kendileri almaya başladılar. Bu da demokrasinin o çağa göre en anlamlı yönetim biçimi oldu. Ancak, Yunan siteleri dahil, daha sonraki tarihlerde toplum birimlerinde değişik sosyal yapılanmalar olmasına karşın, kadın yok sayıldı. Genel olarak toplu yerleşim yerlerinde, Yunan demokrasisi dahil, kadınlar hep üreme ve nesli devam ettirme aracı olarak görüldü, toplumsal yaşam alanları paylaşılmadı.

Sonraki dönemlerde, uzunca bir zaman, kadın ve erkek arasında paylaşılmayan yaşam alanları, gelişmekte olan toplumsal düzen içinde sorgulanmaya başladı. Batı toplumunda, 18. yüzyılda başlayan Endüstri Dönemini içine alan aydınlanma çağı sonrasında üretim alanlarında iş gücünün sağlanması için kadın emeği daha ucuz bir değere satın alındı. Üretim alanlarında sosyalleşen kadın gücü, alışllagelmiş iş dağılımını sorgulamaya ve erkeklerden hiç de farklı olmayan işleri başardıkları için eşit haklar mücadelesi benimseyip dillendirmeye başladılar.

Modern ve laik devlet yapısına dönüşen toplumlarda insan hakları toplum bilincine çıkarıldı. Toplumsal yapı kadını hatırladı ve kadının da topluma her konuda katkı sağlayabileceği kavramını kabul etti. 
Özellikle 1786 devriminden sonra kadın hakları dünya çapında yaygınlaştırıldı, kadın hakları düşüncesi ve eşit hakları konusunda yüzyılımızda genel olarak bir mutabakat sağlandı. Gelişmiş ülkelerde kadınların toplumsal başarıları daha görünür oldu ve o ülkelerde kadınların işgücüne yaptıkları katkılarla toplumsal refah düzeyi arttırılabildi. Ülkemizde kadının oy hakkı toplumsal birey olarak ülke bazında, Cumhuriyet Döneminde ve Atatürk’ün çok önemsediği bir hak olan oy kullanma hakkı 5.Aralık 1934 yılında Anayasa ve seçim yasalarında yapılan değişiklikle tanındı. Atatürk ve yasayı kabul eden meclisimize teşekkür borcumuzu ve ödevimizi biz kadınlar ve kadınlara destek olan erkeklerle yerine getirmek için çalışıyoruz. Çünkü geleneğimiz Han’ın yanında aynı yetkiyi kullanan Hatun'a da saygıyı gerektirir. Ne güzel bir gelişmedir ki, kadın haklarının geliştirilerek kabulü, Dünya Sağlık Örgütü liderliğinde "İstanbul Sözleşmesi” adı altında evrenselleşmiştir. Bu hareket Dünya'da kısa adıyla He for she (Kadın için Erkek) olarak yayılmaktadır ve bu hareket için hazırlanan sözleşme pek çok ülke tarafından-Türkiye de dahil imzalanmıştır. Hareket, ilk yazılı Sümer metinleri dışında, kadının rolünü yeniden eşit bir insan olarak tanıyan evrensel bir belgedir ve yazıya dökülmesi çok önemlidir. Günümüz itibarıyla fizik güç gerektiren işler dışında, yeniden oluşan toplumsal işgücüne katkı açısından, kadının toplumsal eşitliğinin önünde hiçbir şekilde engel olamayacağı da çok açık tarihsel bir gelişmedir. Hiç kuşkusuz, modernleşme ve laik düzenin korunabildiği oranda yaşanan bu gelişmelere paralel olarak, ülkemizde de kadın-erkek eşitliği olgusu toplum içindeki yerini pekiştirerek gelişecektir.

Kadının toplumdaki yeri, günümüzde erkekten çok farklı bir konumdadır. Çünkü kadın, insan neslinin devamını sağlayan doğum olgusunu hala bütün sorumluluğu ile üzerinde taşımaktadır. Bu bağlamda insan yavrusunun YDS bir şekilde beslenmesi böylece yaşama sağlıklı merhaba demesi ve gelişimin en kritik olduğu 1-5 yaş aralığında bu beslenme şeklinin devamlılığının sağlanması, annenin sorumluluğuna bırakılmış durumdadır. Anne sütü verilmesinden başlayarak, çocuğun fizik, biyolojik ve mental gelişiminin en sağlıklı şekilde sağlanabilmesi için annenin YDS beslenmesinin önemi bilinen bir gerçektir. İşte bu noktada babanın anneye desteği çok önemlidir. Diyetisyenler/beslenme ve diyet uzmanları olarak danışanlarımıza YDS desteği verdiğimizde gebelikte beslenmenin önemini, bebeklikte alınacak anne sütünün değerini bebeklikten beş yaşına kadar olan gelişimde YDS’nin ne denli hayati önem taşıdığını çok iyi anlatmamız ve bunu da geliştireceğimiz eğitim stratejileri ile etkin bir şekilde gerçekleştirmemiz gerekiyor. Bu süreç içinde, babanın yer alması ve anneye gereken desteği vermesi durumunda anne sütü veriminin arttığını gösteren araştırma sayısı oldukça fazladır (3). Bu bağlamda danışmanlık yapan diyetisyenlerin/beslenme ve diyet uzmanlarının, babaları çocuk yetiştirme süresince anneye nasıl

Tablo 1. Ülkelerde beklenen yaşam süresi (ilk ve son 10 ülke değerleri) (1)

\begin{tabular}{|c|c|c|c|c|c|c|c|c|c|}
\hline \multicolumn{5}{|c|}{ İlk 10} & \multicolumn{5}{|c|}{ Son 10} \\
\hline Sira & Ülke & Yaş (yul) & $\mathbf{K}$ & $\mathbf{E}$ & Sira & Ülke & Yaş (yıl) & $\mathbf{K}$ & $\mathbf{E}$ \\
\hline 1 & Hong Kong & 84.7 & 87.6 & 81.8 & 175 & Cameroon & 58.9 & 60.2 & 57.7 \\
\hline 2 & Japan & 84.5 & 87.5 & 81.3 & 176 & Equatorial Guinea & 58.4 & 59.6 & 57.4 \\
\hline 3 & Switzerland & 83.6 & 85.5 & 81.7 & 177 & Guinea-Bissau & 58.0 & 59.9 & 56.0 \\
\hline 4 & Singapore & 83.7 & 85.7 & 81.4 & 178 & South Sudan & 57.6 & 59.1 & 56.1 \\
\hline 5 & Italy & 83.4 & 85.4 & 81.1 & 179 & Côte d'Ivoire & 57.4 & 58.7 & 56.3 \\
\hline 6 & Spain & 83.4 & 86.1 & 80.7 & 180 & Nigeria & 54.3 & 55.2 & 53.5 \\
\hline 7 & Australia & 83.3 & 85.3 & 81.3 & 181 & Sierra Leone & 54.3 & 55.1 & 53.5 \\
\hline 8 & Iceland & 82.9 & 84.4 & 81.3 & 182 & Chad & 54.0 & 55.4 & 52.6 \\
\hline 9 & Israel & 82.8 & 84.4 & 81.1 & 183 & Lesotho & 53.7 & 57.0 & 50.6 \\
\hline 10 & South Korea & 82.8 & 85.8 & 79.7 & 184 & Central African Republic & 52.8 & 55.0 & 50.6 \\
\hline
\end{tabular}


destek olmaları gerektiği konusunda da bilgi ve deneyimlerini arttırma sorumluluğu ve zorunluğu bulunmaktadır.

Unutmamamız gereken en önemli nokta, insanın sağlığını etkileyen etmenlerin sadece YDS ile sinırlı olmadığıdır. Son iki dekadlık dönemde yapılan çalışmaların açık bir şekilde gösterdiği gibi, sağlıkta psikolojikfaktörlerin etkisi önemli ölçüde artmaktadır. Danışanlarımıza hizmet verirken bu hususu daima dikkate almalı ve danışanın sorunları için iyi bir dinleyici rolümüzü geliştirmek için çaba göstermeli ve danışanlarımız için psikolog ve psikiyatr desteğini sağlamak için elimizden geleni yapmalıyız. Bu tutum sayesinde bu konuda görev yapan uzmanların da hastalarını bizlere yönlendirebileceğini hiçbir zaman unutmamalıyız. Çünkü çok iyi biliyoruz ki bireyler için geliştirilecek her türlü tedavi planı bireye özeldir. $\mathrm{Bu}$ nedenle birey için geliştirilmesi gereken plan da ancak kişi ile yeterli ve ayrıntılı sorgulamaya imkan verecek uzun görüşme saatleri ile sağlanabilir.

\section{KAYNAKLAR}

1. Worldometer. Life expectancy of world population. August, 2020. Available at: https://www.worldometers. info/demographics/life-expectancy/ Accessed August, 2020.

2. Kutluay-Merdol T. Beslenme Eğitimi ve Danışmanlığı, T.C. Sağlık Bakanlığı Beslenme Bilgi Serisi. Ankara: T.C. Sağlık Bakanlığı; 2008. 10 p.

3. Merdol DS, Türker PF. Anne sütü verimliliği ve emzirme süresi üzerinde baba desteğinin rolü: Diyetisyenlere düşen görevler. Tayfur M, editör. Beslenme ve Diyetetik Güncel Konular 7. Ankara: Hatiboğlu Yayınevi; 2018. 